\title{
Sir Thomas More, Utopia, and the Representation of Henry VIII, 1529-1533
}

\section{J. CHRISTOPHER WARNER}

Summary: This essay examines Sir Thomas More's Utopia in the context of Henry VIII's divorce crisis. During this period tracts from the royal press publicized an image of Henry VIII as a disinterested philosopher-king who welcomed open debate and advice at his court. Reading Morus and Hythlodaeus's dialogue on the subject of court counsel in light of this campaign helps us to perceive the manner in which More's appointment as lord chancellor served the purposes of the king's propaganda.

$\mathrm{U}$ nderstandably, the relevance of Utopia to Henry VIII's divorce crisis has not appeared at all direct, either to historians or literary critics. More's masterpiece had been published over a decade before (in Louvain, in 1516), and beyond Book One's vaguely prophetic concern with avoiding or carefully negotiating the perils of court service, it hardly seems germane to the events of 1529-30. On top of this, More published many treatises in these years which far more obviously pertain to the religious and political context of Henry's effort to obtain a divorce. ${ }^{1}$ But here I do argue that Utopia played an active role in this period, and rather than focusing on More's attempts to reverse the religious and political upheavals of his times, of which his later writings were an important part, I take Henry VIII's propaganda campaign as the most appropriate context within which to understand that role. This campaign's aim was to convince the realm that the king's marriage had been void from its beginning, and that the pope lacked authority, under God and within England, to declare it valid or to forbid Henry from wedding Anne Boleyn. ${ }^{2}$ An explication of the primary strategy for arguing the king's cause will enable us 
to see in what sense Henry VIII, by naming Thomas More as his lord chancellor, acquired Utopia as a means to his own propagandistic representation.

\section{I}

Central to the royal press campaign was an officially publicized image of Henry VIII as a philosopher-king, a sage ruler who welcomed open debate and advice even in this period of crisis. In fact, this strategy extended beyond the medium of print, and in order to characterize its form and purposes I cite first not a treatise but the event that celebrated Henry's success: Anne's coronation procession through London on May 31, 1533. Sidney Anglo describes the elaborate pageant series that accompanied this event in Spectacle, Pageantry, and Early Tudor Policy, working from ambassadors' accounts, the summary in Hall's Chronicle, and a contemporary pamphlet memorializing the event. ${ }^{3} \mathrm{He}$ points out that the series affirmed England's break with Rome through its conspicuous lack of biblical imagery, and its reliance instead on pagan and humanistic themes for praising the new queen. ${ }^{4}$ Two humanist scholars had indeed been charged with planning and conducting the pageant: John Leland, an antiquary employed in the royal libraries, and Nicholas Udall, the Latinist best remembered today for the comedy Ralph Roister Doister (1553), but who in 1533 was known as the author of Flowers for Latin Speaking, selected and gathered out of Terence. Leland and Udall designed classical sets - the nine Muses singing at the fountain of Helicon, for example - and they composed and recited along the procession route verses celebrating Anne's beauty and fertility (she was three months pregnant) and the Golden Age to come, many in classical Latin meters, echoing memorable passages from Horace and Virgil. ${ }^{5}$

Anglo finds this pageant aesthetically disappointing. He contrasts it with the previous two in the century, the first marking Catherine of Aragon's entry into London in 1501, and the second honoring Charles V's visit in 1522. In 1501 , for example, "the whole series had been mathematically symmetrical with almost every allusion relating to a carefully devised scheme," and "the basic concepts employed had been strongly rooted in medieval cosmology, and the imagery had been drawn from medieval pageant tradition ... Now in 1533 two classical scholars devised both pageants and speeches so that for the first time England witnessed a pageant series which seemed truly classical." But, says Anglo, "the humanism was superficial": it had only a "self-conscious Latinity" and "thin veneer of commonplace literary allusions," and with its "indigestible mass of eulogistic Latin verse extolling the beauty, virtues, and 
excellences of Anne Boleyn," it was, in sum, "a dull, trite, and lamentably repetitious pageant series."

In terms of its success in the royal propaganda campaign, however, Anne's coronation pageant associated the king and his court with the fruits of humanism most effectively. Henry VIII, so his subjects see, is an enlightened prince, a philosopher-king who has surrounded himself with this chorus of humanists who now in the streets of London sing his and his queen's praises and, presumably, provide him not only with the imaginative luggage of their classical learning, but with their moral and political wisdom as well.

In the same way, contemporary tracts published by the royal printer, Thomas Berthelet, implied Henry VIII was just such a humanistic scholar- or philosopherking, a learned and temperate ruler who solicits the counsel of wise men assembled at his court, in the universities, and in the two houses of Parliament. The most famous example is the 1531 Gravissimae, atque exactissimae illustrissimarum totius Italiae, et Galliae Academiarum censurae, printed soon afterwards in translation as The Determinations of the Most Famous and Most Excellent Universities of Italy and France, that it is So Unlawful for a Man to Marry his Brother's Wife, that the Pope hath No Power to Dispense Therewith. ${ }^{7}$ G. R. Elton observes that while this treatise demonstrates how early "Henry VIII and Cromwell discovered the use of printing as an instrument for convincing the people of their claims," it nevertheless maintains a curious "reticent delicacy." "The most remarkable thing about it," says Elton, "is the fact that it never once mentions King or Queen or the particular marriage dispute. A stranger coming upon it would have to regard it as a peculiar academic exercise."8

What makes it so peculiarly academic is the way the Determinations presents itself as the collected conclusions reached by independent-minded academics and theologians throughout Christendom to a deliberative argument on a géneral question - an argument made merely on its own account. In the terminology of the rhetoric handbook, the Determinations is the product of debates "consisting in the discussion of policy" rather than of particular persons or courses of action. These are "causes in which the subject of itself engenders the deliberation," in which "extraneous motives" are not considered, and "the entire discourse is devoted to the subject itself." In other words, this is an exercise in "philosopher talk" - the kind of discourse about truth and virtue that humanists engage in when they meet in their gardens and villas, and, so it was implied, at Henry's court.

This image was designed to assure the realm that such a king, guided by such good counsel, was directing the government's actions in what everyone 
recognized were dangerous times. As Henry moved closer toward open defiance of Rome over the issue of his marriage, he increasingly risked excommunication and a declaration by Pope Clement VII of a holy war against England. In addition, Charles V of Spain was Catherine's nephew, and rumor had it that he was prepared to invade at once if Henry dared to cast off his queen. This threat was taken so seriously that the Duke of Norfolk, head of Henry's council, asked Charles's ambassador in England outright whether or not Spain would attack if the English Church granted Henry his divorce. ${ }^{10}$ Henry was determined to have his way despite the dangers, but he was also anxious to minimize them by encouraging his subjects not to think him a tyrant. The philosopher-king image lent itself to this public relations campaign not only because it pictured Henry amidst a circle of wise and admiring counselors, but also because it appeared to allow space for dissent, portraying Henry as a disinterested seeker after truth who, for the good of the realm, welcomed open debate and truthful counsel. This image would help to allay fears at home, and discourage enemies' hopes both at home and abroad, that the ship of state was being piloted by a lone and unpopular tyrant ripe for overthrowing by foreign invasion or popular uprising. ${ }^{11}$

This was not, of course, the first time Henry cultivated a philosopher-king image. Humanism's ideology and practices had once before served him well when other methods had failed. In 1521 the title he coveted but could not win by the usual means of battle victories - defensor fidei, "defender of the faith" - Pope Leo X granted him for writing abook against Luther, the Assertio Septem Sacramentorum adversus $M$. Lutherum. ${ }^{12}$ Though it hardly set back the advance of the Reformation, this work did publicize a self-image and it did inspire the kind of praise for which Henry was eager. ${ }^{13}$ Nor was this the first time, outside England, that both the press and the philosopher-king image were used to justify an absolute ruler's supremacy. Quentin Skinner reminds us, for example, that tracts arguing for the concentration of power in the hands of a single "prudent and philosophical ruler" began to appear in Florence in the 1470s and 1480s, when Lorenzo de Medici was intent on combating a growing popular nostalgia for the city's republican past. ${ }^{14}$ When Henry VIII met with resistance to his planned divorce from Catherine of Aragon, therefore, the cultivation of a philosopher-king image was a strategy based both on historical precedent and personal, past success, so it naturally became a key tactic in pursuing his "great matter."

We observe the strategy again in Kotser Codicis R. Wakfeldi (Berthelet, 1533), in which Robert Wakefield, England's foremost Hebrew scholar in the reign of Henry VIII, analyzes the biblical passages pertaining to the divorce question. Appended to this treatise is a letter from Richard Pace to Henry VIII 
explaining how Wakefield was originally encouraged to study the problem. Pace reminds the king of another book arguing against the validity of his marriage, which Pace had himself composed (after consulting Wakefield) and had presented to Henry for his evaluation. At that time, Pace recalls, "it pleased your grace to show unto me, that some of your learned counsel had written that the book of the old law named Deuteronomy, doth take away and annul the other book named Leviticus" (sig. P3r). ${ }^{15}$ Pace remembers assuring his king that "such opinions can in no wise be true," but Henry was not easily convinced. Shortly afterwards, Wakefield heard of these continued doubts and asked Pace if he thought Henry would wish him to examine further the scriptural evidence pertaining to his case in its original language, to discover, as Pace puts it, "whether it were against you or for you." Finally, Pace tells Henry the answer he gave Wakefield: "That your grace intended nothing, but that was convenient to the person of a noble and a virtuous prince, and that he should do unto your grace right acceptable service, if he would study for to show unto you the said truth of the matter" (sig. P3v).

In the process of telling his story, Pace represents the king acting with the same "reticent delicacy" Elton attributes to the Determinations of the Most Famous Universities. According to this portrait Henry so values truth that he prudently hesitates to embrace the opinions Pace and Wakefield offer in support of his case. Henry's own "learned counsel" has compiled counter-arguments against the Levitical law that theologians every where are citing to deny the validity of his marriage (so the Determinations purports to show), and the king himself forwards these on to others who might too rashly judge in his favor. This does not mean that the king will forever be a bystander in the debate: Pace also says in his letter that he is sending Henry a Hebrew alphabet, and he speaks of Henry having "within the space of one month ... sufficient knowledge of the Hebrew tongue, for to judge thereby the Latin translation" of the relevant passages himself (sigs. $\mathrm{P}^{\mathrm{v}}-4^{\mathrm{r}}$ ). But in the meantime the king withholds his judgment, waiting to hear from all sides in this disputation among experts.

\section{II}

We may raise the issue of More's difficult role in Henry's service with reference to a letter he wrote to Thomas Cromwell in 1534, defending himself against the charge of opposition to the king's marriage to Anne Boleyn. More there states that despite his personal feelings he had agreed, when offered the chancellorship in 1529, not to hinder Henry's efforts to have his marriage to 
Catherine nullified. Henry at the time assured him, says More, that he would never "put any man in ruffle or trouble of his conscience."16 Other evidence indicates, however, that the king pressured More constantly, from the first year the divorce became an issue, in 1527, until More's resignation from office in 1532, both to accept the view that the royal marriage was invalid and to assist in the court's negotiations with Rome to have the cause returned to England for trial. ${ }^{17}$ Given Henry's failure to win More's support in this of all matters, we may well wonder why More got the job in the first place. John Guy proposes he did because More "was the man of the moment, because a layman was required as chancellor, because he knew best the judicial work of Council and Chancery, and because he was not [a] protégé" of the unpopular Cardinal Thomas Wolsey, his predecessor in the office. ${ }^{18}$ Furthermore, says Guy, More's "appointment as lord chancellor seems plainly to have rested partly on the miscalculation that [Henry] could win More round sooner or later to supporting the divorce." ${ }^{19}$ By promoting him to lord chancellor, in other words, Henry would have put More under a greater obligation to serve according to his king's conscience, or rather, to come to the realization that his own conscience and his king's ought properly to be in accord. Henry could reasonably have hoped, then, that More's change of heart would shortly follow his promotion.

More's change of heart did not come at all, and Henry grew increasingly impatient with his chancellor's stubborn refusal to get involved in the court's most important business. Within a year after More took office, in fact, Imperial ambassador Chapuys wrote to Charles V that "the chancellor is still in danger of being dismissed, and this solely because he hesitated to sign with the others [certain of] the king's letters to the pope." 20 That More was not dismissed, I suggest, owed as much to his advertising value as to his expertise in civil law. Borrowing Elton's words, "More was Henry's pledge of Renaissance excellence, his intellectual courtier," 21 though here I ascribe to Henry a more deliberately propagandistic stratagem than Elton intended. To wit, Henry's reasons for promoting More included his desire to demonstrate to his subjects that he was serious about promoting humanist ideals at his court, and despite the fact that More would do what he could afterwards to oppose the divorce, Henry nonetheless conceived of More as one element in his campaign to represent himself as a philosopher-king.

In 1529 More was suited for Henry's employment in this way because of his fame both at home and on the Continent as the leading humanist in England. He was a friend of Erasmus, and according to Erasmus's recently published praise of him More was not only a man of broad learning and personal integrity 
but a very "Socrates in wisdom." 22 In addition, More's latest publications were anti-Protestant polemics - the Responsio ad Lutherum (1523) and A Dialogue concerning Heresies (1529) — so his appointment contributed to Henry's public image as defender of the faith, a champion of the Church whose allegiance the pope would not wish to lose over such a matter as a request for a divorce.

Thomas More was also, however, the author of Utopia, an internationally acclaimed work of moral and political philosophy, but one that contains a powerful condemnation of kings. In Book Two Raphael Hythlodaeus describes the state of Utopia to Morus and Petrus because they have challenged him to name an alternative to what he sees is the inherently flawed system of monarchy, a system of government that naturally leads - as he had asserted in Book One - to tyranny and social injustice. ${ }^{23}$ Morus does refute Hythlodaeus's judgment, but, as critics have always remarked, rather lamely. Even so, in my view Utopia began in 1529 to do work for the king. Firstly, it models the kind of inquiry into a general question - what would be the best state of a commonwealth? that oppositional discourse could take in order to demonstrate Henry's openness and tolerance, and yet still be safely vague about his specific failings. Secondly, it reflects very well on Henry that the author of such a persuasive case against entering a king's service would agree to enter into his.

We may appreciate the several dimensions of these flattering implications for Henry by examining that crucial passage at the end of Utopia's Book One in which Hythlodaeus and Morus put forth their opposing philosophies of counsel. ${ }^{24}$ The scene of their exchange is the private garden of a house in Antwerp, where Morus is residing while on break from his diplomatic duties. $\mathrm{He}$ is in conversation with his friend Petrus and a new acquaintance, a world traveler and student of Greek philosophy, Raphael Hythlodaeus. ${ }^{25}$ Petrus expresses surprise that Hythlodaeus is not already in some king's service, and Hythlodaeus explains that if he were, he would either have to tell lies in order to win his master's favor, or give frank advice that he knows would be resented. Since his soul "abhors" all falsehood and flattery, he knows he is safest far from the courts of kings. To this Morus replies:

To tell the truth, I do not think that such ideas should be thrust on people, or such advice given, as you are positive will never be listened to. What good could such novel ideas do, or how could they enter the minds of individuals who are already taken up and possessed by the opposite conviction? In the private conversation of close friends this academic philosophy is not without its charm, but in the councils of kings, where great matters are debated with great authority, there is no room for these notions (p. 99). 
Hythlodaeus answers that this is "just what [he] meant ... by saying there is no room for philosophy with rulers," a conviction that will soon lead him to describe Utopia, which like Plato's model republic flourishes because its rulers are philosophers. ${ }^{26}$ How much happier that land will appear to us, he promises, than the tyrannies of Europe. But before Hythlodaeus is invited to describe Utopia, Morus tries again to rebut his opinion of court counsel, by offering a philosophy that allows an honest man to serve his king whatever his king's faults:

There is another philosophy, more practical for statesmen, which knows its stage, adapts itself to the play in hand, and performs its role neatly and appropriately. This is the philosophy which you must employ. Otherwise we have the situation in which a comedy of Plautus is being performed and the household slaves are making trivial jokes at one another and then you come on the stage in a philosopher's attire and recite the passage from the Octavia where Seneca is disputing with Nero. Would it not have been preferable to take a part without words than by reciting something inappropriate to make a hodgepodge of comedy and tragedy [fecisse tragicomoediam]? You would have spoiled and upset the actual play by bringing in irrelevant matter even if your contribution would have been superior in itself. Whatever play is being performed, perform it as best you can, and do not upset it all simply because you think of another which has more interest.

So it is in the commonwealth. So it is in the deliberations of monarchs. If you cannot cure according to your heart's desire vices of long standing, yet you must not on that account desert the commonwealth. You must not abandon the ship in a storm because you cannot control the winds.

On the other hand, you must not force upon people new and strange ideas which you realize will carry no weight with persons of opposite conviction. On the contrary, by the indirect approach you must seek and strive to the best of your power to handle matters tactfully. What you cannot turn to good you must at least make as little bad as you can (pp. 99-101).

Morus's conception of a counselor's duty, we note, does not contest Hythlodaeus's claim that kings tend to be tyrants. He virtually accepts tyranny as a given, as we gather from the aesthetic and rhetorical principle of decorum that lies behind his advice to Hythlodaeus. The counselor guided by this principle, which requires that each element of an artwork or persuasive speech be appropriate to its context, ${ }^{27}$ will take into account particularities of place and time and audience, judge how much good he can do and by what means, and in the long run accomplish the most good for king and commonwealth through his circumspection. There is not much room for a Henry VIII, philosopher-king, in 
this picture, for Morus acknowledges that straightforward admonishments to wise policy and virtuous actions are not the ordinary - because they are the least effective - modes of counsel. The wise counselor must use discretion, adapt himself to the play at hand, hold his tongue at one moment and at another dissemble, in order to make things "as little bad as possible" (quam minime malum) in serving a king inclined to follow his own will.

The implications of this passage's classical sources prove even more critical of monarchy, because the drama analogy that is the vehicle for Morus's advice to Hythlodaeus is itself equivocal and, as Arthur Kinney observes, adds "a darker undercurrent to the witty disputation on the surface" of Book One. ${ }^{28}$ We are asked to imagine an actor interrupting a Plautine comedy with lines from Seneca's disputation with Nero in the Roman history play, Octavia. ${ }^{29}$ Though these lines may be "more superior" in themselves, says Morus, they are ill-timed and ineffective "in the play at hand." Yet Seneca's disputation with Nero represents something more complex than just a piece of tragic drama contaminating the aesthetic coherence of a comedy: there is disturbing irony in the fact that even within Octavia Seneca's words fail to abide by the rules of decorum. Like Hythlodaeus Seneca can only speak his mind, and his persistence in dissuading Nero from doing what he has already made up his mind to do - banish his wife from Rome (of all things) - only provokes the emperor's anger: "Have done at last; you are already growing too burdensome to me. One may still be permitted to do what Seneca disapproves" (lines 58889).

Renaissance readers were familiar with Seneca's life and fate through The Annals of Tacitus, whose account makes Nero's anger in the above scene all the more chilling, and Morus's position seem all the more naive. Seneca and Afranius Burrhus were charged with training and counseling the young Nero, or as Tacitus puts it, their task was "to ensure that the sovereign's years of temptation should, if he were scornful of virtue, be restrained within the bounds of permissible indulgence" (13.2). In other words, they had to try to make Nero as little bad as possible. But Seneca was eventually accused of conspiring against the emperor, and Nero ordered him to commit suicide (15.61). Accordingly Seneca became for Renaissance humanists a hallowed martyr, illustrating, like the fates of Socrates and Cicero, the end to which good men come in times of tyranny. In a passage devoted to the importance of decorum in Thomas Starkey's Dialogue between Pole and Lupset, for instance, Pole illustrates his point that "a man must regard time and place if he will handle matters of state" with the case of Seneca, who, "if [he] had not been in the time of Nero, 
so cruel a tyrant, but in the time of Trajan, so noble a prince, his virtue should have been otherwise esteemed, and brought forth other fruit." 30

Cicero suffered the same misfortune, Pole continues, because he lived under Pompey and Caesar, and appropriately enough the passage from Utopia that we are analyzing also contains allusions to Cicero's writings and career. Utopia's Yale editors compare Morus's advice for Hythlodaeus to a repeated maxim in De officiis: "Of two evils choose the least" (Primum minima de malis $[3.28 .102,3.29 .105]),{ }^{31}$ while George Logan points to a longer passage in the same work in which Cicero states, "if at some time stress of circumstances shall thrust us aside into some uncongenial part, we must devote to it all possible thought, practice, and pains, that we may be able to perform it, if not with propriety, at least with as little impropriety as possible" (si non decore, at quam minime indecore $[1.31 .114]) .{ }^{32}$ The Yale editors are right, too, in naming Plato as the source of Morus's ship-pilot metaphor, and in pointing out that this was a stock symbol of the statesman throughout antiquity and the Middle Ages. ${ }^{33}$ But More is also recalling a specific passage in Cicero's letter to Publius Lentulus Spinther of December, 54 B.C., in which Cicero defends himself for supporting the joint dictatorship of the First Triumvirs (Caesar, Pompey, and Crassus):

In sailing, it shows nautical skill to run before the wind in a gale, even if you fail thereby to make your port; whereas when you can get there just as well by tacking, it is sheer folly to court disaster by keeping your original course, rather than change it and still reach your desired destination. On the same principle in the conduct of state affairs, while we should all have as our one aim and object what I have so repeatedly preached - the maintenance of peace with honor - it does not follow that we ought always to speak in the same way, though we ought always to have the same goal in view (non idem semper dicere, sed idem semper spectare debemus, Ad familiares 1.9.21)

It would indeed be "sheer folly" for Cicero to speak publicly in the manner that he could while consul (63 B.C.) and before the formation of the triumvirate, or as he may in this private exchange of letters with a friend. One's words "must agree with the times" (temporibus assentiendum), Cicero explains, and as More looks back to Cicero - to the tumultuous times in which the model statesman lived, and his horrible end at the hands of Mark Antony - he found both an authority and a case in point for Morus's argument in Utopia: since virtuous rulers are few and far between, men must adapt themselves to living and effecting good under tyrannies.

When he offered Utopia's author the position of lord chancellor, Henry certainly did not intend that the world would interpret the appointment as 
More's opportunity to effect good under a tyrant. Rather, if readers believed that Hythlodaeus was More's real spokesman in the dialogue, and Morus was what his name means in Latin $(f o o l)$, then More's acceptance of the great seal would have indicated that he had found in Henry an exception to Hythlodaeus's claim that kings are by nature tyrants and that only flatterers serve them. A good man, in this reign, could with a clear conscience serve his king. But as far as Henry's image was concerned it did not matter that one took Hythlodaeus's or Morus's views to be the author's own, for in either case More's appointment could only appear to be the decision of a Trajan. Only a true philosopher-king would seek out a man so committed to speaking the blunt truth as a Hythlodaeus; only a king who wanted the best for himself and his realm would knowingly employ a man who had publicly embraced a policy of covert opposition as the usual method for serving kings.

Such implications suggest that More's appointment was, in part, one aspect of the king's propaganda program: the new lord chancellor contributed, as a public figure and humanist author, to Henry's construction of a philosopher-king public image, whether or not Henry planned in practice to heed, or even hear, his wisest counselor's advice.

\section{Kent State University}

\section{Notes}

1. These are The Supplication of Souls (1529), The Confutation of Tyndale's Answer (1532), The Second Part of the Confutation of Tyndale's Answer (1533), The Apology of Sir Thomas More, Knight (1533), A Letter against Frith (1533), The Debellation of Salem and Bizance (1533), and The Answer to a Poisoned Book (1534). I follow general practice in referring to Henry and Catherine's "divorce," but technically Henry was seeking a declaration from the pope that his marriage had never been valid. The standard accounts of the divorce crisis are in Geoffrey de C. Parmiter's The King's Great Matter: A Study of Anglo-Papal Relations, 1527-1534 (New York: Barnes and Noble, 1967) and J. J. Scarisbrick's Henry VIII (Berkeley: University of California Press, 1968), chapters 7-10. Henry claimed his marriage to Catherine was invalid on the basis of the prohibitions in Leviticus 18.16 and 20.21 against a man marrying the wife of his brother, as Henry had done after Catherine was left a widow by the death of Prince Arthur, in 1502. At Henry VII's request, Pope Julius II awarded a dispensation to allow the marriage, but in 1527 Henry started to insist that no one, not even the pope, could dispense with divine law. Those who opposed Henry's interpretation of Leviticus held that the stricture only prohibited one from "uncovering the nakedness" of the wife of a still living brother (as Tyndale concludes in The Practice of Prelates: see Expositions and Notes on Sundry Portions of the Holy Scriptures, together with the Practice of Prelates, by William Tyndale, Martyr, 1536, edited for the Parker Society by Rev. Henry Walter [Cambridge: Cambridge University Press, 1849], p. 328). 
2. In recent decades historians have demonstrated that Henry's propaganda campaign was initiated earlier, and directed by the king to a greater degree, than had traditionally been supposed. See especially Steven Haas, "The Disputatio inter clericum et militem: Was Berthelet's 1531 Edition the First Henrician Polemic of Thomas Cromwell?" Moreana, 14 (1977): 65-72; John Guy, Christopher St. German on Chancery and Statute, Selden Society Supplementary Series, vol. 6 (London: Selden Society, 1985), pp. 19-55, and the same author's "Thomas More and Christopher St. German: The Battle of the Books," in Alistair Fox and John Guy, Reassessing the Henrician Age: Humanism, Politics and Reform, 15001550 (Oxford and New York: Basil Blackwell, 1986), pp. 95-120.

3. The eyewitness accounts and official rolls of the participants are calendared in J. S. Brewer, James Gairdner, et. al., eds., Letters and Papers, Foreign and Domestic, of the Reign of Henry VIII (hereafter LP), 21 vols. (London: Longmans and HMSO, 1862-1932), vol. 6, nos. 561-63, 585, 653; Pascual de Gayangos, ed., Calendar of State Papers, relating to the Negotiations between England and Spain (hereafter SP, Spanish), 13 vols. (London: Longmans and HMSO, 1862-1954), vol. 4, pt. 2, nos. 704, 1100, 1107. See also Edward Hall, Hall's Chronicle containing the History of England . . to the end of the reign of Henry Eight, ed. Sir Henry Ellis (London: J. Johnson, 1809), pp. 798-805; The Noble Triumphant Coronation of Queen Anne, Wife unto the Most Noble King Henry the VIIIth, rpt. in Edward Arber, An English Garner: Ingatherings from our History and Literature, 8 vols. (Westminster: A. Constable, 1893-97), vol. 2, pp. 41-51. This tract was printed by Wynkyn de Worde for John Gough under the king's privilege. Gough seems to have printed only a few books, but half of these had a government connection; he printed a description the previous year, for instance, of The Manner of the Triumph at Calais and Boulogne, also with the king's privilege (rpt. in Arber, An English Garner, vol. 2, pp. 33-40).

4. Anglo, Spectacle, Pageantry, and Early Tudor Policy (Oxford: Clarendon Press, 1969), p. 247.

5. The manuscript of these verses is calendared in $L P$, vol. 6 , no. 564, and printed in Frederick J. Furnivall, ed., Ballads from Manuscripts, 2 vols. (London and Hertford: Ballad Society, 1868-73), vol. 1, pp. 378-413; Udall's English verses only are in Arber, An English Garner, vol. 2, pp. 52-60.

6. Spectacle, Pageantry, and Early Tudor Policy, p. 248.

7. The Censurae and Determinations are reprinted in Edward Surtz, S. J. and Virginia Murphy, eds., The Divorce Tracts of Henry VIII (Angers: Moreana, 1988). The Censurae is dated 1530 in $S T C$, but Murphy argues it was printed in 1531. On the collection of these authoritative opinions see also Henry Ansgar Kelly, The Matrimonial Trials of Henry VIII (Stanford: Stanford University Press, 1976), 173-89; Parmiter, The King's Great Matter, pp. 120-43. For an illuminating discussion of the strain that politics put on scholars' biblical interpretations pertaining to the validity of Henry's marriage, see Guy Bedouelle, "The Consultations of the Universities and Scholars Concerning the 'Great Matter' of King Henry VIII," trans. John L. Farthing, in The Bible in the Sixteenth Century, ed. David C. Steinmetz (Durham: Duke University Press, 1990), pp. 21-36.

8. G. R. Elton, Policy and Police: The Enforcement of the Reformation in the Age of Thomas Cromwell (Cambridge: Cambridge University Press, 1972), p. 175. 
9. Rhetorica ad Herennium, 1.2.2 and 3.2.2. All citations of the Roman classics are from the Loeb series, but I have adjusted the translations.

10. SP, Spanish, vol. 4, pt. 1, no. 290.

11. This was the characterization of Henry that Catherine's English allies were presenting Chapuys, and that Chapuys was sending on to Charles. See, for example, $L P$, vol. 7 , no. 1206.

12. Henry dedicated the Assertio to Pope Leo X. On the dubiousness of the king's sole authorship of this tract see Philip Hughes, The Reformation in England, 3 vols. (London: Hollis and Carter, 1950-54), pp. 146-48; Scarisbrick, Henry VIII, p. 115.

13. Shortly after the Assertio's publication, for instance, the renowned humanist teacher at the University of Rome, Pierius Valernius, said about Henry and his treatise in a public lecture that, "The most pious writings of this king are in the hands of all — so learned, so devout, so ardent - by which he has most successfully demolished the most vile enterprises of the Lutheran faction (or should I say, pestilence?) which had begun to overthrow the laws, religion, and all secular things; so that you may understand from this one man what hope exists for the future if, as Plato argued, citizens will be of the same quality as their kings" (Praelectiones in Catullum [Vat. Lat. 5215], fols. 162 ${ }^{\mathrm{v}}-163^{\mathrm{r}}$, quoted and translated by Julia Haig Gaisser in Catullus and his Renaissance Readers [Oxford: Clarendon Press, 1993], pp. 132-33, 348 n. 102).

14. See "Political Philosophy," in Charles B. Schmitt and Quentin Skinner, eds., The Cambridge History of Renaissance Philosophy (Cambridge: Cambridge University Press, 1988), pp. 426-30. The examples Skinner cites of works extolling monarchy as "the best state of a commonwealth" are the Disputationes Camaldulenses by Cristoforo Landino and De legibus et iudiciis by Bartolomeo Scala, Lorenzo's chancellor.

15. Here and below I have modernized the original spelling.

16. The Correspondence of Sir Thomas More, ed. E. F. Rogers (Princeton: Princeton University Press, 1947), no. 199.

17. On the forms of this pressure see Elton, "Sir Thomas More and the Opposition to Henry VIII," in Bulletin of the Institute of Historical Research, 41 (1968): 19-21; rpt. in Elton, Studies in Tudor and Stuart Politics and Government, 3 vols. (Cambridge: Cambridge University Press, 1974-83), vol. 1, pp. 155-57; John Guy, The Public Career of Sir Thomas More (Brighton: Harvester Press, 1980), pp. 99-103; and Richard Marius, Thomas More (New York: Knopf, 1984), pp. 361-62.

18. Guy, The Public Career of Sir Thomas More, p. 97.

19. Ibid., 101.

20. $S P$, Spanish, vol. 4 , pt. 1 , no. 460.

21. Elton, "Thomas More, Councillor," in St. Thomas More: Action and Contemplation, ed. R. S. Sylvester (New Haven: Yale University Press, 1972), p. 110; rpt. in Elton, Studies in Tudor and Stuart Politics and Government, vol. 1, p. 147.

22. Erasmus's most famous portraits of More appear in two letters, one to Ulrich von Hutten and 
the other to Guillaume Budé (see The Collected Works of Erasmus, ed. R. J. Schoeck and B. M. Corrigan [Toronto: University of Toronto Press, 1974-], vol. 7, no. 999 and vol. 8, no. 1233; the numbering is that of the standard modern Latin edition, Opus epistolarum Des. Erasmi Roterodami, ed. P. S. Allen, M. H. Allen, and H. W. Garrod, 12 vols. [Oxford: Oxford University Press, 1906-58]). Three editions of Erasmus's letters were printed in the 1520 s, including Froben's monumental Opus epistolarum of 1529, the year of More's appointment.

23. Critics ordinarily refer to the characters Morus and Petrus by their real-life names, More and Peter Giles, but here I will refer to all three characters in Utopia by their Latin names, to sustain the distinction between More and his fictional self-representation, and so keep in the foreground our uncertainty about the likeness of their views.

24. This section of Utopia is at the center of the debate over More's sincerity or irony in voicing (through Hythlodaeus) an attack on the system of monarchy and (through Morus) an explication of the counselor's duty to serve under tyrants. See, for example, J. H. Hexter, "Thomas More and the Problem of Counsel," in Michael J. Moore, ed., Quincentennial Essays on St. Thomas More: Selected Papers from the Thomas More College Conference (Boone, NC: Albion, 1978), 55-66; Quentin Skinner, "Sir Thomas More's Utopia and the Language of Renaissance Humanism," in Anthony Pagden, ed., The Languages of Political Theory in Early Modern Europe (Cambridge: Cambridge University Press, 1987), 123-57.

25. Hythlodaeus, says Petrus, is "most learned in Greek" and has "devoted himself unreservedly to philosophy": "His sailing has not been like that of Palinurus but that of Ulysses or, rather, of Plato" (The Complete Works of St. Thomas More [hereafter CW], ed. Louis L. Martz, Richard S. Sylvester, Clarence H. Miler, et. al., 15 vols. [New Haven: Yale University Press, 1963-], vol. 4, 49 and 51; the original Latin text is on facing pages).

26. See Republic 5.473c-e, in Plato: The Collected Dialogues, ed. Edith Hamilton and Huntington Cairns, (Princeton: Princeton University Press, 1961).

27. As Horace prescribes in Ars poetica and Cicero in his rhetorical works (e.g., De oratore 3.55.210-60.225).

28. Humanist Poetics: Thought, Rhetoric, and Fiction in Sixteenth-Century England (Amherst: University of Massachusetts Press, 1986), pp. 70-72. The "tragic irony" of this analogy is also discussed, though in a different sense than mine below, by John Crossett in "More and Seneca," Philological Quarterly, 40 (1961): 577-80.

29. The author of Octavia is unknown, but in More's time it was still attributed to Seneca himself.

30. Thomas Starkey: A Dialogue between Pole and Lupset, ed. T. F. Mayer, Camden Fourth Series, vol. 37 (London: Royal Historical Society, 1989), p. 15.

31. $C W$, vol. 4,374 n. 100/1-2.

32. George M. Logan, The Meaning of More's "Utopia" (Princeton: Princeton University Press, 1983), 116 n. 73.

33. $C W$, vol. 4 , 373 n. 98/27, citing Republic 6.488a-489a. 